\title{
An unusual oro-naso-sinus communication resulting from heroin and cocaine snorting
}

\author{
Lovely Chhabra, George M Abraham
}

Department of Internal Medicine, Saint Vincent Hospital, University of Massachusetts Medical School, Worcester, Massachusetts, USA

\section{Correspondence to} Dr Lovely Chhabra, lovids@hotmail.com

\section{DESCRIPTION}

A 28-year-old woman with a history of snorting heroin and cocaine was admitted with facial cellulitis secondary to a dental phlegmon. She reported rhinolalia, occasional nasal regurgitation of food and a burning sensation in her nose and throat while eating. She self-medicated with a topical application of crushed acetaminophen and oxycodone tablets to her throat to prevent discomfort while eating.

Physical examination revealed poor dentition, palatal destruction, absent soft palate and a white substance (acetaminophen powder) at the posterior

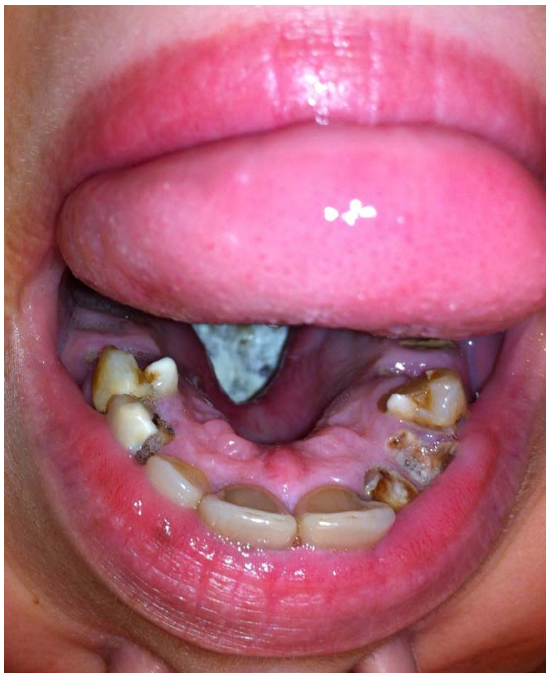

Figure 1 A view of her oral cavity revealed poor dentition, hard palatal perforation, absent soft palate and the presence of a whitish substance (acetaminophen) on the posterior pharyngeal wall and buccal mucosa. pharyngeal wall and buccal mucosa (figure 1). Contrast-enhanced CT scanning revealed palatal perforation with complete absence of soft palate, absent nasal septum and a communication between the oropharynx, the nasopharynx and the left maxillary sinus (figure $2 \mathrm{~A}-\mathrm{C}$ ). Her odontogenic abscess was treated with clindamycin and she was referred for surgical reconstruction of the palate.

The vasoconstrictive and caustic effects, resulting from the snorting of recreational drugs, especially cocaine, can produce direct irritation and ischaemia of the nasopalatine mucosa, leading to the creation of an oro-nasal perforation secondary to maxillary bone destruction. ${ }^{1}{ }^{2}$ Management consists of a combination of antibiotics, analgesics, prostheses (obturators) and surgical reconstruction of the defect. $^{2}$

Our case represents a very rare complication sustained from the deleterious effects of cocaine, 'oro-naso-sinus fistula' rather than just an oronasal fistula.

\section{Learning points}

Palatal perforation is a rare complication, which can occur in patients snorting recreational drugs such as cocaine. It results from the direct caustic and vasoconstrictive effects of the drugs.

- The most frequent clinical manifestation is rhinolalia together with the regurgitation of solid food and liquids through the nares.

- Management consists of a combination of antibiotics, analgesics, prostheses (obturators) and surgical reconstruction of the defect.
To cite: Chhabra L, Abraham GM. BMJ Case Rep Published online: [please include Day Month Year] doi:10.1136/bcr-2013010450
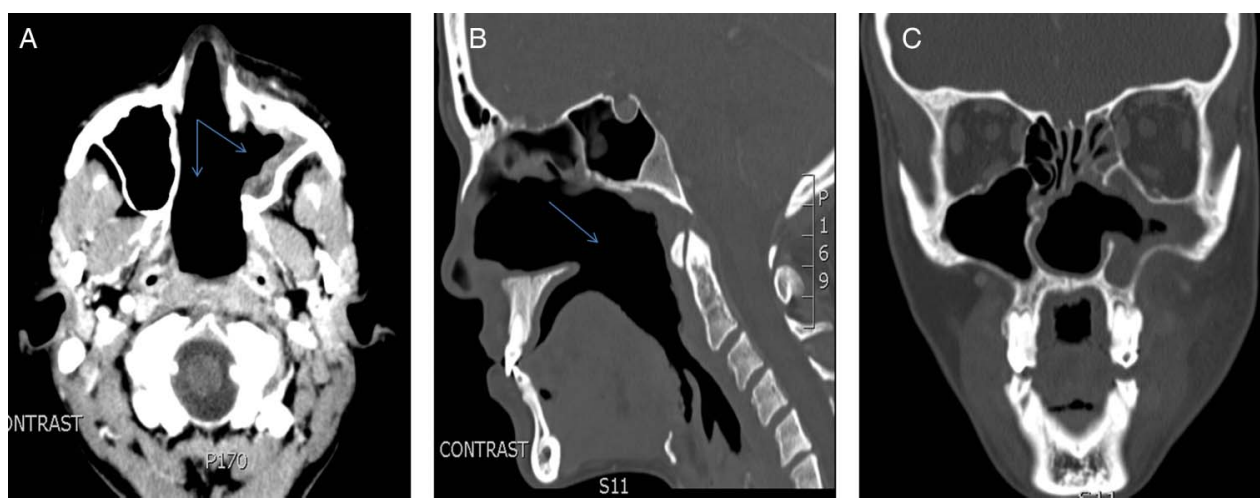

Figure 2 (A) CT scan (cranio-facial view) reveals a communication between the oropharynx, the nasopharynx and the left maxillary sinus (oro-naso-sinus fistula). (B) Sagittal view reveals complete absence of the soft palate. (C) Coronal view reveals a naso-sinus communication, and a palatal tear. 
Competing interests None.

Patient consent Obtained.

Provenance and peer review Not commissioned; externally peer reviewed.

\section{REFERENCES}

1 Lypka MA, Urata MM. Images in clinical medicine. Cocaine-induced palatal perforation. N Engl J Med 2007;357:1956.

2 Silvestre FJ, Perez-Herbera A, Puente-Sandoval A, et al. Hard palate perforation in cocaine abusers: a systematic review. Clin Oral Investig 2010;14:621-8.

Copyright 2013 BMJ Publishing Group. All rights reserved. For permission to reuse any of this content visit

http://group.bmj.com/group/rights-licensing/permissions.

BMJ Case Report Fellows may re-use this article for personal use and teaching without any further permission.

Become a Fellow of BMJ Case Reports today and you can:

- Submit as many cases as you like

- Enjoy fast sympathetic peer review and rapid publication of accepted articles

- Access all the published articles

- Re-use any of the published material for personal use and teaching without further permission

For information on Institutional Fellowships contact consortiasales@bmjgroup.com

Visit casereports.bmj.com for more articles like this and to become a Fellow 